Original Research Paper

\title{
HUBUNGAN PERUBAHAN POLA BELAJAR TERHADAP STRES DAN PRESTASI AKADEMIK PADA MASA PANDEMI COVID-19
}

\author{
Anna Tasya Cindywieka, Ajeng Afni Kartika, Masdalena, Erwin Handoko* \\ Fakultas Kedokteran, Universitas Prima Indonesia
}

Email Corresponding*: erwinhandoko@unprimdn.ac.id

Page : 52-58

Kata Kunci : Pola belajar, stres, prestasi akademik, COVID-19

Keywords : Learning style, stress, academic achievement, COVID-19

Published by:

Tadulako University,

Managed by Faculty of Medicine.

Email: healthytadulako@gmail.com

Phone (WA): +6285242303103

Address:

Jalan Soekarno Hatta Km. 9. City of

Palu, Central Sulawesi, Indonesia
Di bidang pendidikan kedokteran, pola belajar yang diterapkan pada saat ini berpotensi menimbulkan stres pada mahasiswa. Fakultas Kedokteran di Indonesia menganut cara pembelajaran berbasis masalah (problem-based learning) yang terpusat pada mahasiswa (student-centered learning). Proses pembelajaran yang terpusat pada mahasiswa dalam kegiatan belajar dan mengajar tersebut, bila tidak dikelola dengan tepat akan mengakibatkan stres berlebih yang pada akhirnya memengaruhi kemampuan belajar dan prestasi akademik mahasiswa. Karena itu, penelitian ini bertujuan untuk mempelajari apakah terdapat perubahan yang berarti pada pola belajar dan hubungannya terhadap stres serta prestasi akademik pada mahasiswa kedokteran. Dilakukan penelitian cross-sectional terhadap 193 mahasiswa/i fakultas kedokteran Universitas Prima Indonesia. Adapun parameter yang diukur dalam penelitian ini meliputi: pola belajar, tingkat stres, prestasi akademik dan hubungan antara perubahan pola belajar, stres dan prestasi akademik. Penelitian ini menggunakan metode analisis uji korelasi Pearson dan mendapati hasil bahwa 184 dari 193 orang mahasiswa/i fakultas kedokteran Universitas Prima Indonesia memiliki tingkat stres normal, 167 mahasiswa/i merasakan terdapat perubahan pola belajar selama berkuliah daring dan ditemukan hubungan yang signifikan antara tingkat stres dan pola belajar strategi deep serta stres dan prestasi akademik. Dapat disimpulkan bahwa terdapat hubungan antara perubahan pola belajar strategi deep dengan stres dan stres dengan prestasi akademik mahasiswa/i Universitas Prima Indonesia.

\section{ABSTRACT}

In medical education, the current learning pattern is potential to cause stress to students. The Faculty of Medicine in Indonesia adheres to a problem-based learning model that is centered on students. The student-centred learning process in teaching and learning activities, if not managed properly, will result in excessive stress which in turn affects students' learning abilities and academic achievement. This study aims to study whether there are significant changes in learning style and their relationship to stress and academic achievement in medical students. A crosssectional study was conducted on 193 students of the medical faculty of the Prima Indonesia University. Parameters measured in this study include: learning style, stress levels, academic achievement and the relationship between changes in learning style, stress and academic achievement. This study used the Pearson correlation test and found that 184 out of 193 students had normal stress levels, 167 students felt that there was a change in learning style during online lectures and there was a significant relationship between stress levels and deep strategy learning style and between stress and academic achievement. In conclusion, there is a relationship between learning style with stress and between stress with academic achievement of Prima Indonesia University students.

\section{PENDAHULUAN}

Pandemi COVID-19 bukan hanya berdampak pada bidang kesehatan, tetapi juga pada banyak bidang kehidupan lainnya, 
termasuk pendidikan. Untuk mencegah peningkatan kasus COVID-19, Kementerian Pendidikan dan Kebudayaan menginstruksikan agar aktivitas perkuliahan dilakukan secara daring. ${ }^{1}$ Perubahan metode pengajaran yang terjadi secara drastis ini dapat menimbulkan beberapa perubahan dalam proses pembelajaran, tak terkecuali pada pola belajar. Perubahan pola belajar yang dapat terjadi secara mendadak berpotensi untuk menimbulkan stres pada mahasiswa yang dapat berdampak pada prestasi akademik mereka.

Pola belajar merupakan suatu metode yang menjadi karakteristik seseorang dalam proses memperoleh ilmu pengetahuan. ${ }^{2}$ Dikarenakan proses kognisi yang mencakup proses mental tiap individu berbeda, maka proses belajar tiap individu akan berbeda pula. Secara umum, pembelajar dibagi menjadi dua yaitu orang yang ingin memahami pelajaran yang dipelajari dan orang yang hanya ini sekedar lulus mata pelajaran tersebut. Yang menjadi perbedaan antara keduanya adalah pendekatan yang diterapkan untuk belajar di mana dalam poin-poin tertentu hal ini berkaitan dengan pola belajar.

Pendekatan pembelajaran sendiri merupakan integrasi antara alasan belajar, lingkungan belajar, dan strategi belajar. Untuk menunjukkan hubungan antara ketiga faktor tersebut, Biggs ${ }^{3}$ mengajukan model 3P, sebuah sistem yang terdiri atas tiga tahapan mendasar dalam pembelajaran yaitu presage (sebelum belajar), proses (faktor yang berkaitan dengan proses pembelajaran) dan produk (hasil belajar yang diperoleh).

Di bidang pendidikan kedokteran, pola belajar yang diterapkan pada saat ini berpotensi menimbulkan stres pada mahasiswa. Fakultas Kedokteran di Indonesia menganut cara pembelajaran berbasis masalah (problembased learning) yang terpusat pada mahasiswa (student-centered learning). Proses pembelajaran yang terpusat pada mahasiswa dalam kegiatan belajar dan mengajar tersebut, bila tidak dikelola dengan tepat akan mengakibatkan stres berlebih yang pada akhirnya memengaruhi kemampuan belajar dan prestasi akademik mahasiswa. ${ }^{4}$ Sehingga, tidak sedikit studi yang telah melaporkan bahwa tingkat stres yang dialami mahasiswa kedokteran cukup tinggi.

Beban stres yang berlebih dapat berakibat pada kualitas performa belajar mahasiswa, seperti penurunan antusias untuk menghadiri perkuliahan, penundaan penyelesaian tugas, hingga penyalahgunaan zat terlarang dan alkohol. ${ }^{5}$ World Health Organisation (WHO) ${ }^{6}$ mengatakan "Kesehatan mental ialah kesejahteraan seorang individu yang sadar akan kesanggupannya sendiri, dapat menangani tekanan hidup yang wajar, produktif dalam bekerja dan berbuah, serta dapat berkontribusi pada komunitasnya".

Meskipun demikian, kesejahteraan sulit diterapkan sebagai komponen pokok dari kesehatan mental mengingat banyaknya situasi kehidupan yang menantang di mana kesejahteraan bahkan mungkin dianggap tidak sehat. Stres ialah dampak dari segala perbuatan dan keadaan dari lingkungan yang menyebabkan tuntutan psikis maupun fisik yang berlebihan pada seseorang. Stres tidak dapat dihindari dari berbagai aspek kehidupan, semua orang dapat mengalami stres, yang menjadi perbedaan adalah tingkat stres yang rendah atau tinggi, jangka waktu yang dialami dan cara individu menghadapi stres. ${ }^{5}$

Studi oleh Paiboonsithiwong $\mathrm{S} \mathrm{dkk}^{2}$ menunjukkan prestasi akademik berhubungan dengan pola belajar akan tetapi untuk mahasiswa kedokteran sendiri belum diketahui apakah pola belajar juga berdampak pada prestasi akademik. Pola belajar juga dapat memprediksi pendekatan dan kepuasan mahasiswa kedokteran terhadap pekerjaan, stres dan kesehatan mental baik saat mendaftar ke fakultas kedokteran maupun di tahun terakhir. Prestasi akademik juga dikaitkan dengan prestasi masa depan mahasiswa 
kedokteran di jenjang pendidikan dokter spesialis $^{2}$.

Pandemi COVID-19 menyebabkan perubahan yang drastis pada proses belajar dan mengajar di Fakultas Kedokteran seluruh dunia, termasuk Indonesia. Saat ini, Fakultas Kedokteran di Indonesia mengadopsi pendekatan belajar daring atau bauran untuk mengurangi penyebaran COVID-19. Perubahan ini bukan hanya berdampak pada metode pembelajaran, tetapi juga pada pola interaksi pengajar dengan pelajar, antarpelajar serta pada pola belajar pelajar. Hal ini berpotensi meningkatkan beban psikologis yang dialami mahasiswa di Fakultas Kedokteran. Akan tetapi, masih sedikit sekali studi yang telah dilakukan terkait permasalahan perubahan pola belajar di masa pandemi COVID-19, tingkat stres yang dialami, serta prestasi akademik mahasiswa.

Penelitian ini bertujuan untuk mempelajari apakah terdapat perubahan yang berarti pada pola belajar dan hubungannya terhadap stres serta prestasi akademik pada mahasiswa kedokteran. Penelitian ini menggunakan instrumen The Revised Two Factors Study Process Questionnaire atau RSPQ-2F untuk mempelajari pola belajar mahasiswa, serta The Depression, Anxiety and Stress Scale atau DASS-21 untuk mempelajari mengenai tingkat stres mahasiswa.

\section{BAHAN DAN CARA}

Pelaksanaan penelitian ini bertempat di Fakultas Kedokteran Universitas Prima Indonesia, Sumatera Utara pada bulan Maret Oktober 2021 dengan sampel mahasiswa/i semester 2,4 dan 6 dari salah satu Fakultas Kedokteran swasta terbesar di Sumatera Utara. Adapun responden pada penelitian ini berjumlah 193 orang dan survei dilakukan secara daring.

Penelitian ini menggunakan kuesioner

The Revised Two Factors Study Process Questionaire atau R-SPQ-2F yang belum ada versi dengan Bahasa Indonesia sehingga dilakukan penerjemahan terlebih dahulu. Selain itu, digunakan kuesioner Depression, Anxiety and Stress Scale atau DASS-21 serta dikumpulkan Indeks Prestasi Kumulatif (IPK) dari responden. Setelah proses penerjemahan kuesioner selesai, disusun daftar pertanyaan yang menjadi data dalam penelitian ini dan kuesioner disebarkan secara daring. Satu minggu sejak disebarkan, diberi pengingat sebanyak tiga kali dengan jarak yang sama.

Setelah data dikumpulkan, kelengkapan data diperiksa kembali dan data yang dikumpulkan dikode menjadi angka agar memudahkan proses pengolaan data. Data kemudian diolah dengan IBM SPSS menggunakan uji korelasi Pearson. Hasil dari analisis kemudian dipresentasikan dalam bentuk deskriptif.

\section{HASIL}

Mayoritas dari responden pada penelitian ini adalah wanita, yaitu sebanyak 129 responden, dengan jumlah responden pria sebanyak 64 responden. Berdasarkan semester, responden terbanyak berasal dari semester 6 , yaitu sebanyak 72 responden. Sementara itu, ditinjau dari indeks prestasi kumulatif (IPK), karakteristik reponden dari penelitian ini yaitu: semester 6 (pria: 3,13; wanita: 3,00), semester 4 (pria: 3,25; wanita: 3,06) dan semester 2 (pria: 2,91; wanita: 2,97). Rangkuman karakteristik responden ditampilkan pada Tabel 1 .

\section{Tabel 1 Karakteristik Mahasiswa Peserta Penelitian Pola Belajar, Stres dan Prestasi Akademik}

Dari hasil survei, $167 \quad(86,53 \%)$ mahasiswa/i melaporkan adanya perubahan pada pola belajar mereka selama masa pandemi bila dibandingkan dengan sebelum masa pandemi. Tabel 2 menampilkan rincian data 


\begin{tabular}{|c|c|c|c|c|}
\hline Semester & Gender & Jumlah & $\begin{array}{c}\text { Rata-rata } \\
\text { Usia } \\
\text { Rata-rata }\end{array}$ & $\begin{array}{l}\text { Rata-rata } \\
\text { IPK } \\
\text { Rata-rata }\end{array}$ \\
\hline \multirow[t]{2}{*}{2} & Pria & 14 & 19 & 2,91 \\
\hline & Wanita & 43 & 19 & 2,97 \\
\hline \multirow[t]{2}{*}{4} & Pria & 22 & 20 & 3,25 \\
\hline & Wanita & 42 & 20 & 3,06 \\
\hline \multirow[t]{2}{*}{6} & Pria & 28 & 21 & 3,13 \\
\hline & Wanita & 44 & 21 & 3,00 \\
\hline \multicolumn{5}{|c|}{$\begin{array}{l}\text { persepsi mahasis } \\
\text { belajar tersebut. }\end{array}$} \\
\hline Tabel 2 & $\begin{array}{l}\text { 2. Perse } \\
\text { Pola } \\
\text { Pande }\end{array}$ & $\begin{array}{l}\text { psi Mal } \\
\text { Belaja } \\
\text { mi }\end{array}$ & $\begin{array}{l}\text { hasiswa/i } \\
\text { r Dala }\end{array}$ & $\begin{array}{l}\text { Mengenai } \\
\text { m Masa }\end{array}$ \\
\hline \multirow[t]{2}{*}{ Semester } & Gender & \multicolumn{3}{|c|}{$\begin{array}{c}\text { Apakah Anda merasa ada } \\
\text { perubahan pada pola belajar Anda } \\
\text { sebelum masa pandemi COVID-19 } \\
\text { dan sekarang? }\end{array}$} \\
\hline & & ya & & tidak \\
\hline \multirow[t]{2}{*}{2} & Pria & 11 & & 3 \\
\hline & Wanita & 38 & & 5 \\
\hline \multirow[t]{2}{*}{4} & Pria & 19 & & 3 \\
\hline & Wanita & 37 & & 5 \\
\hline \multirow[t]{3}{*}{6} & Pria & 23 & & 5 \\
\hline & Wanita & 39 & & 5 \\
\hline & Total & 167 & & 26 \\
\hline
\end{tabular}

Mahasiswa yang melaporkan adanya perubahan pola belajar juga diminta menjelaskan mengenai perubahan yang mereka alami. Lima tema utama yang dilaporkan mahasiswa/i mengenai perubahan:

1) Mahasiswa/i merasa menjadi lebih malas karena waktu yang ada digunakan untuk bersantai.

2) Mahasiswa/i merasa sulit untuk fokus, sehingga timbul kurangnya pemahaman mengenai mata kuliah yang dilaksanakan secara daring.

3) Mahasiswa/i merasa lebih banyak waktu luang selama kuliah daring sehingga waktu yang ada dapat dihabiskan untuk mengulang mata kuliah.
4) Mahasiswa/i merasa kuliah daring lebih menuntut mahasiswa/i untuk dapat belajar secara mandiri, sehingga mahasiswa/i banyak mencari sumber informasi di luar mata kuliah yang diberikan.

5) Mahasiswa/i merasa terdapat perubahan gaya belajar sejak kuliah daring dari yang tadinya mahasiswa/i menghafal mata kuliah yang diberikan tanpa mengerti isi dari materi tersebut menjadi lebih berusaha untuk mengerti materi kuliah yang diberikan daripada menghafalnya.

Tabel 3 menunjukkan rangkuman laporan responden mengenai tingkat stres yang diukur dengan DASS21. Dari tabel tersebut, secara umum, didapatkan bahwa sebagian besar tingkat stres mahasiswa/i Fakultas Kedokteran yang diteliti adalah normal $(n=184)$, diikuti ringan $(\mathrm{n}=8)$, dan sedang $(\mathrm{n}=1)$. Berdasarkan jenis kelamin, dari 129 orang responden wanita, 121 melaporkan tingkat stres normal, diikuti dengan 7 orang yang mengalami stres ringan, satu orang dengan stres berat. Sementara itu, dari 64 mahasiswa pria yang mengembalikan survei, didapati 63 mahasiswa dengan tingkat stres normal dan satu mahasiswa dengan tingkat stres ringan.

\section{Tabel 3. Tingkat Stres Pada Mahasiswa/i Fakultas Kedokteran yang diteliti}

\begin{tabular}{lcccc}
\hline Karakteristik & \multicolumn{5}{c}{ Tingkat Stres } \\
\cline { 2 - 5 } \multicolumn{1}{c}{ Responden } & Normal & Ringan & Sedang & Total \\
\hline Jenis Kelamin & & & & \\
Pria & 63 & 1 & 0 & 64 \\
Wanita & 121 & 7 & 1 & 129 \\
\hline Usia & & & & \\
17-21 tahun & 176 & 8 & 1 & 185 \\
$22-31$ tahun & 8 & 0 & 0 & 8 \\
\hline Semester & & & & \\
2 & 55 & 2 & 0 & 57 \\
4 & 60 & 3 & 0 & 63 \\
5 & 1 & 0 & 0 & 1 \\
\hline
\end{tabular}




\begin{tabular}{lccc}
\hline 6 & 66 & 3 & 1 \\
7 & 2 & 0 & 0 \\
& & & \\
& & & \\
Hasil & uji & statistik & korelasi \\
memperlihatkan & adanya hubungan yang \\
signifikan secara statistik antara subskala deep \\
motive dengan tingkat stres. Di
\end{tabular}

Tabel 4 Korelasi Stres dan Prestasi Akademik Mahasiswa/i yang Diukur dengan IPK

\begin{tabular}{|c|c|c|c|c|c|c|}
\hline & IPK & Stres & $\begin{array}{l}\text { Deep } \\
\text { Motive }\end{array}$ & $\begin{array}{c}\text { Deep } \\
\text { Strategy }\end{array}$ & $\begin{array}{l}\text { Surface } \\
\text { Motive }\end{array}$ & $\begin{array}{l}\text { Surface } \\
\text { Strategy }\end{array}$ \\
\hline IPK & & $\begin{array}{r}- \\
\end{array}$ & 0,130 & 0,133 & $-0,052$ & $-0,120$ \\
\hline stress & & & $-0,108$ & $-0,156^{*}$ & 0,046 & 0,025 \\
\hline $\begin{array}{l}\text { Deep } \\
\text { Motive }\end{array}$ & & & & $0,808^{* *}$ & $0,239^{* *}$ & $0,329^{\text {*** }}$ \\
\hline $\begin{array}{l}\text { Deep } \\
\text { Strategy }\end{array}$ & & & & & $0,180^{*}$ & $0,298^{* *}$ \\
\hline $\begin{array}{l}\text { Surface } \\
\text { Motive }\end{array}$ & & & & & & $0,657^{* *}$ \\
\hline $\begin{array}{l}\text { Surface } \\
\text { Strategy }\end{array}$ & & & & & & \\
\hline
\end{tabular}

*. Korelasi signifikan, $\mathrm{p} \leq 0,05$

$* *$. Korelasi signifikan, $\mathrm{p} \leq 0,01$

\section{PEMBAHASAN}

Tingkat stres mahasiswa/i Fakultas Kedokteran yang diteliti menunjukkan hasil yang normal dengan mayoritas responden wanita yaitu sebanyak 121 orang. Hal ini berbeda dengan hasil penelitian mengenai gambaran tingkat stres berdasarkan stresor pada mahasiswa tahun pertama FK (Fakultas Kedokteran) Universitas Andalas oleh Rahmayani dkk (2019) yang melaporkan bahwasanya mahasiswa tahun pertama mengalami stres sedang yang serupa dengan hasil penelitian yang dilakukan oleh Inama $S$ (2021)..$^{7,8}$

Hasil uji statistik korelasi prestasi akademik dengan tingkat stres memperlihatkan bahwa ditemukan hubungan yang signifikan di mana semakin tingi tingkat stres, semakin rendah prestasi akademik. Hasil ini tidak sesuai dengan hasil penelitian Panma, Yuanita (2021) yang menggunakan instrumen Student Life Stress Inventory Questionnaire dalam pengukuran tingkat stres mahasiswa. ${ }^{9}$

Stres yang dialami oleh mahasiswa/i dapat disebabkan oleh berbagai macam penyebab seperti faktor akademik yang dapat memicu reaksi fisik, pikiran serta emosi. Selain itu, terdapat juga faktor internal yaitu bagaimana pola pikir, kepribadian serta keyakinan seorang mahasiswa/i. Faktor sosial, pengendalian diri, aktivitas kelompok dan faktor keinginan juga dapat memengaruhi tingkat stres dari mahasiswa/i. ${ }^{7}$

Stres yang timbul dapat disebabkan oleh sistem kuliah daring di masa pandemi COVID19 di mana mahasiswa/i tidak bisa berinteraksi dengan dosen maupun dengan mahasiswa/i lain seperti biasanya sehingga mahasiswa/i dapat mengalami kesulitan dalam proses belajar mengajar yang dapat memicu timbulnya stres akademik. Kepribadian dan pengendalian diri dari mahasiswa/i yang sering kali menundanunda untuk mengerjakan tugas atau pembelajaran juga dapat menyebabkan stres saat mendekati ujian karena menumpuknya pekerjaan yang harus dilakukan.

Berdasarkan survei yang dilakukan, 167 dari 193 responden mahasiswa/i Fakultas Kedokteran yang diteliti, merasakan adanya perubahan pada pola belajar sebelum dan sesudah pandemi COVID-19/kuliah daring. Adapun perubahan yang dirasakan mayoritas menjadi lebih buruk di mana pada sistem daring mahasiswa lebih mudah terdistraksi sehingga mahasiswa mudah bosan lalu muncul kurangnya pemahaman terhadap mata kuliah 
yang diajarkan. Selain dampak negatif yang muncul dari sistem perkuliahan daring, ada juga dampak positif yang diberikan pada perubahan pola belajar mahasiswa/i FK di mana mahasiswa/i menjadi lebih banyak membaca sumber-sumber informasi di luar mata kuliah yang diberikan. Selain itu, bertambahnya waktu luang pada sistem perkuliahan daring banyak digunakan oleh mahasiswa/i untuk mengulang kembali mata kuliah yang telah diajarkan kemudian mahasiwa/i mengubah gaya belajar yang tadinya menghafal menjadi memahami isi dari mata kuliah.

Dari penelitian didapatkan hubungan yang negatif, kecil dan signifikan antara pola belajar dengan strategi deep dan stres. Ditemukan hubungan yang kecil, negatif dan signifikan secara statistik antara prestasi akademik dan tingkat stres. Di mana hal ini berarti apabila stres yang dialami semakin berat, maka akan semakin rendah pula prestasi akademik. Serta terdapat hubungan yang kecil/tidak berarti antara pola belajar dan prestasi akademik.

Hal ini tidak sejalan dengan hasil studi yang dilaporkan Imtiaz I dkk ${ }^{4}$ pada tahun 2019 yang mengungkapkan bahwasanya tidak ada korelasi antara pola belajar dengan stres dan prestasi akademik berdasarkan VARK (visual, aural, read/write \& kinesthetic) versi 7.8 dan The Perceived Stress Scale versi 10.0. Telah dilakukan studi yang tidak mengidentifikasi adanya hubungan yang berarti antara stres dan prestasi akademik pada mahasiswa kedokteran tingkat akhir. Studi ini bertolak belakang dengan hasil penelitian Paiboonsithiwong $S$ dkk (2016) yang juga menyatakan bahwa tidak ada hubungan antara pola belajar, stres dan prestasi akademik. $^{2}$

Berdasarkan hasil studi, perubahan pola belajar pada mahasiswa/i FK Universitas Prima Indonesia tidak menyebabkan stres dan tidak berpengaruh pada prestasi akademik. Menurut peneliti, hal ini dapat terjadi karena perubahan- perubahan positif yang terjadi pada mahasiswa/i seperti menjadi lebih banyak membaca sehingga tingkat stres akademik mahasiswa/i dapat menjadi lebih rendah.

\section{KESIMPULAN DAN SARAN}

Berdasarkan studi yang telah dilakukan, dapat disimpulkan bahwa mayoritas tingkat stres mahasiswa/i FK Universitas Prima Indonesia adalah normal yaitu sebanyak 184 dari 193 orang responden dan tidak terdapat hubungan yang berarti antara hubungan perubahan pola belajar stres dan prestasi akademik. Akan tetapi didapatkan bahwa semakin berat stres yang dialami mahasiswa/i maka semakin rendah prestasi akademik.

Peneliti sadar bahwa penelitian ini belum sempurna. Karenanya, dibutuhkan penelitian lebih lanjut terhadap pengukuran pola belajar, tingkat stres dan prestasi akademik untuk mengetahui hubungannya.

\section{UCAPAN TERIMA KASIH}

Penulis mengucapkan terima kasih kepada semua pihak yang telah mendukung serta membantu pelaksanaan penelitian ini dari awal sampai akhir.

\section{DAFTAR PUSTAKA}

1. Kemendikbud. Surat Edaran Mendikbud. Published online 2020:1.

2. Paiboonsithiwong S, Kunanitthaworn N, Songtrijuck N, Wongpakaran N, Wongpakaran T. Journal of Educational Evaluation for Health Professions Learning styles and academic achievement among undergraduate medical students in Thailand. $J E d u c$ Eval Health Prof. 2016;13(38):1-6.

3. Astika G, Sumakul DTYG. ELTR Journal, e-ISSN 2579-8235 ,. 2020;4(1):36-42.

4. Imtiaz I, Nisa $M$, Hina $S$, et al. Association of Learning Style and Stress 
With Academic Achievement Among Physical Therapy Students. J Riphah Coll Rehabil Sci. 2019;(0):1. doi:10.5455/jrcrs.2019070204

5. Sutjiato M, GD K, AAT T. Hubungan Faktor Internal dan Eksternal dengan Tingkat Stress pada Mahasiswa Fakultas Kedokteran Universitas Sam Ratulangi Manado. J ilmu Kesehat Masy UNSRAT. 2015;5(1):1-8.
9. Panma Y. Relationship Between Academic Stress and Learning Achievement in Nursing Student. Int J Educ Res Soc Sci. 2021;2(1):222-229. doi:10.51601/ijersc.v2i1.43

6. BENOIT EP. Toward a new definition of mental retardation. Am J Ment Defic. 2015;63(4):559-565.

7. Rahmayani RD, Liza RG, Syah NA. Gambaran Tingkat Stres Berdasarkan Stressor pada Mahasiswa Kedokteran Tahun Pertama Program Studi Profesi Dokter Fakultas Kedokteran Universitas Andalas Angkatan 2017. J Kesehat Andalas. 2019;8(1):103. doi:10.25077/jka.v8i1.977

8. Inama S. Gambaran Tingkat Stres Mahasiswa Fakultas Kedokteran Universitas Sumatera Utara Dalam Sistem Pembelajaran Daring Pada Era Pandemi Covid-19. Published online 2021:46. 